\title{
'n Ondersoek na die Nuwe-Testamentiese makarisme en makarismereeks as Gattung
}

\author{
AG van Aarde
}

Indem die Aufgaben [der formen- und gattungskritische Methode] ... kommt deutlich das Dilemma der gegenwärtigen Forschungssituation zum Ausdruck ... So kann zwar die Methode der Formen - und Gattungskritik dargestellt werden ... aber es kann in der Regel nicht auf die Ergebnisse ihrer Anwendung verwiesen werden. Diese noch ausstehenden Ergebnisse dürften in vielen Fällen diejenigen der bisher geübten "Form - und Gattungsgeschichte" modifizieren, in manchen Fällen sogar umstossen (Markert 1976: 86).

Die feit dat in Romeine 4:6 en 9 die substantief ho makarismos as benaming gebruik word vir die twee betrokke segginge wat tussen hierdie twee verse voorkom - segginge wat met mekaar bepaalde formele eienskappe in gemeen het - laat ons vermoed dat ons met 'n vaste tipe uitspraak te doen het. Verskeie navorsers het in hulle ondersoeke na dié tipe uitspraak reeds opgemerk dat die makarisme een van die mees algemene formele uitdrukkings in die Griekse taal is (kyk o.a. Votaw 1909: 14b; Hauck 1942: 369 v). Daar bestaan ook talle formgeschichtliche studies na die makarisme as sodanig. (Vir bibliografie, kyk Van Aarde 1978: 116.) Die tradisionele formgeschichtliche benadering vertoon egter ernstige leemtes (kyk Van Aarde HTS 36/1 en 2: 58-73). Dit is byvoorbeeld nie gemotiveerd om van 'n Gattung te praat slegs wanneer daar op die oog af bepaalde formele ooreenkomste tussen segginge en passasies blyk te bestaan nie. Daar kan eers van ' $n$ Gattung sprake wees as daar ten minste twee onafhanklike literêre eenhede bestaan wat in struktuur èn inhoud karakteristieke verwantskap toon (Richter 1971: 138; Markert 1976: 85). 'n Sodanige ondersoek ten opsigte van die Nuwe-Testamentiese makarisme is, sover my kennis strek, nog nie gedoen nie.

In die onderhawige artikel word, na aanleiding van wat genoem kan word 'n "nuwe benadering tot Gattungsforschung" (kyk Van Aarde HTS 36/1 en 2: 58-73), die Nuwe-Testamentiese makarisme en makarismereeks as Gattung ondersoek. Daar sal eers aangetoon word of daar wel 'n Gattung soos die makarisme in die Nuwe Testament bestaan, en indien wel, of die reeks in Matteus 5:3-10'n representant daarvan is of nie. Die ondersoek val hoofsaaklik in twee dele uiteen, naamlik die identifisering van die Gattung en tweedens die bepaling van die Sitz im Leben en funksie. Die vraag na die "funksie" van die 
Gattung is anders as die ander fasette van Gattungsforschung nie hipoteties-operasioneel van aard nie, maar het betrekking op ' $n$ aktuele gebruiksgeval. Die makarismereeks in Matteus 5:3-10 word vir dié doel as illustrasiemateriaal gebruik. Die gattungsgeschichtliche vraag ten opsigte van die makarisme het reeds in die bestaande formgeschichtliche ondersoeke heelwat aandag gekry. Gattungsgeschichtliche kwessies sal daarom in hierdie artikel alleen kortliks te berde gebring word.

\section{Die identifisering van die makarisme as Gattung}

Die identifisering van 'n Gattung kan eers geskied nadat ' $n$ tipiese groep van literêre eenhede of passasies geïsoleer is. Dié tipiese groep bestaan, soos reeds hierbo vermeld, uit ten minste twee onafhanklike literêre eenhede of passasies wat in struktuur èn inhoud verwant is. Perikoopafgrensing en semantiese struktuuranalise is vir die isolering van só 'n tipiese groep onontbeerlik (kyk Van Aarde HTS 36/1 en 2: 64). Omdat die bepaalde literêre eenheid waarin ons hier geïnteresseerd is, altyd 'n kort vaste konstruksie vertoon, is ' $n$ perikoopafbakening en 'n struktuuranalise, soos in die geval van groter eenhede, nie nodig nie. Ons maak slegs 'n ontleding van die grammaties-sintaktiese konstruksie en die semantiek daarvan. Met die oog op 'n vergelykende ondersoek word ' $n$ tabel van al die wyses waarop die woord makarios, -ia, -ion en die ander derivate formeel (grammaties en sintakties) in die Nuwe Testament gekonstrueer word, gebied. Die semantiek van die betrokke woordgroep word daarna oorsigtelik omskryf. Hierdie werkwyse sal die isolering van 'n tipiese groep moontlik maak.

Wanneer ons die verskillende vorme met mekaar vergelyk, kan ons 'n baie breë verdeling maak tussen die adjektiewe, die substantiewe en die werkwoordelike vorme. Die adjektiewe konstruksie kom in die oorgrote meerderheid van die gevalle voor.

\section{A. Substantiewe vorm:}

Rom 4:6 kathaper kai David legei ton makarismon tou anthrōpou... Rom 4:9 ho makarismos oun houtos epi tèn peritomèn è kai epi tén akrobustian;

Gal 4:15 pou oun ho makarismos humōn;

B. Werkwoordelike vorm:

Luk 1:48 idou gar apo tou nun makariousin me pasai hai geneai. Jak 5:11 idou makarizomen tous hupomeinantes. 
C. Die adjektiewe vorm verdeel in 'n predikatiewe en attributiewe gebruik.

Ten opsigte van laasgenoemde bestaan daar in die hele Nuwe Testament slegs vier voorbeelde wat sintakties ook nog met mekaar verskil.

(a) Attributiewe adjektief:

Hand 26:2 peri pantōn hōn egkaloumai hupo Ioudaiōn, basileu Agrippa, hëgèmai emauton makarion epi sou mellōn sēmeron apologeisthai...

1 Tim 1:11 ... kata to euangelion tès doxēs tou makariou theou...

1 Tim 6:15 ... hên kairois idiois deixei ho makarios kai monos dunastēs...

Tit 2:13 ...p prosdechomenoi tēn makarian elpida...

(b) Predikatiewe adjektief:

In hierdie groepering bestaan daar 'n opvallende sintaktiese onderskeid tussen twee tipes. In die een groep funksioneer die makarios, -ia, -ion altyd sintakties as die logiese mikpunk in die segging, en in die ander groep as die uitgangspunt van die segging.

(i) Predikatiewe adjektief wat funksioneer as die logiese mikpunt in die segging:

Luk 12:38 kan en tē deutera kan en tē tritē fulakē elthē kai heurē houtōs, makarioi eisin ekeinoi.

Jak 13:17 ei tauta oidate, makarioi este ean poiète auta.

Hand 20:35(b) ... mnēmoneuein te tōn logōn tou kuriou Iésou hoti autos eipen, Makarion estin mallon didonai è lambanein.

Jak 1:25 ho de parakupsas eis nomon teleion ton tēs eleutherias ... houtos makarios en té poièsei autou estai.

1 Pet 3:14 all' ei kai paschoite dia dikaiosunēn, makarioi.

1 Pet 4:14 ei oneidizesthe en onomati Christou, makarioi, hoti to tēs doxēs kai to tou theou pneuma ef' humas anapauetai.

(b) (ii) Wat hierdie groepering betref (waar die predikatiewe adjektief makarios, -ia, -ion sintakties as die uitgangspunt van die segging funksioneer) kan die volgende verdere grammatiese en sintaktiese opmerkinge gemaak word: Die modus van die adjektief is uit die aard van die saak altyd die nominatief. Die geslag en die getal word bepaal in terme van die substantief (of die partisipiale frase wat in die plek van 'n substantief funksioneer) wat predikatief deur die adjektief omskryf word. Soms is die subjek waarna die makarios, -ia, - 
ion verwys, versweë. Dit is egter altyd vanuit die konteks duidelik bepaalbaar. Dikwels word die subjek met 'n partisipiale frase uitgebrei en in baie gevalle vind daar delesie van die koppelwerkwoord plaas. In die meeste gevalle word die matrikssin uitgebrei met 'n motiverende bysin wat ingelei word met of 'n hoti-bysin, of 'n gar-bysin, of 'n hina-bysin, of ' $n$ relatiewe bysin, of ' $n$ temporele bysin. Slegs in een geval is die adjektief in die komparatiewe trap; die res kom in die stellende trap voor. Om die sintaktiese en grammatiese beskrywing van hierdie groepering op te som: Ons vind in hierdie groepering ' $n$ vaste sintaktiese konstruksie waarin die predikatiewe makarios, -ia, -ion, altyd as die uitgangspunt van die segging funksioneer, maar waar die res wat daarop volg sintakties en grammaties varieer. Vervolgens gee ek 'n tabel van hierdie groepering. Eers word dié segginge sonder die motiverende bysin vermeld, en daarna, dié met die motiverende bysin.

Sonder die motiverende bysin:

Luk 11:27 ... Makaria hē koilia hè bastasasa se kai mastoi hous ethēlasas.

Luk 11:28 ... Menoun makarioi hoi akouontes ton logon tou theou kai fulassontes.

Luk 10:23 makarioi hoi ofthalmoi hoi blepontes ha blepete.

Joh 20:29 makarioi hoi më idontes kai pisteusantes.

Opb 14:13 Makarioi hoi nekroi hoi en kuriō apothnēskontes ap'arti.

Opb 19:9 Makarioi hoi eis to deipnon tou gamou tou arniou keklēmenoi.

Opb 20:6 makarios kai hagios ho echōn meros en tē anastasei tē protē.

Opb 22:7 makarios ho tērōn tous logous tēs profēteias tou bibliou toutou.

Met 'n motiverende hina-bysin:

Opb 16:15 makarios ho grēgorōn kaj tērōn ta himatia autou, hina mē gumnos peripatē kai blepōsin tēn aschēmosunēn autou.

Opb 22:14 makarioi hoi plunontes tas stolas autōn, hina estai hè exousia autōn epi to xulon tēs zōēs kai tois pulōsin eiselthōsin eis tēn polin.

Met 'n motiverende relatiewe bysin:

Matt 11:6 makarios estin, hos ean mē skandalisthē en emoi.

Matt 24:46 makarios ho doulos ekeinos hon elthōn ho kurios autou heurēsei houtōs poiounta.

Luk 7:23 makarios estin hos ean mè skandalisthè en emoi. 
Luk 12:37 makarioi hoi douloi ekeinoi, hous elthōn ho kurios heurèsei grègorountas.

Luk 12:43 makarios ho doulos ekeinos, hon elthōn ho kurios autou heurèsei poiounta houtōs.

Luk 14:15 makarios hostis fagetai arton en tē basileia tou theou.

Luk 23:29 makariai hai steirai kai hai koiliai hai ouk egennèsan kai mastoi hoi ouk ethrepsan.

Rom 4:7-8 makarioi hōn afethēsan hai anomiai kai hōn epekalufthèsan hai hamartiai makarios anēr hou ou mē logisètai kurios hamartian.

Rom 14:22 makarios ho mē krinōn heauton en hö dokimazei.

Met ' $n$ temporele bysin, of kondisionele ean-sin:

Matt 5:11 makarioi este hotan oneidisōsin humas kai...

Luk 6:66 makarioi este hotan misēsōsin humas hoi anthrōpoi.

1 Kor 7:40 makariōtera de estin ean houtōs meinė,...

Met motiverende gar-bysin:

Opb 1:3 makarios ho anaginōskōn kai hoi akouontes tous logous tes profēteias kai tērountes ta en autē gegrammena, ho gar kairos engus.

Met 'n motiverende hoti-bysin:

Matt 5:3 makarioi hoi ptōchoi tō pneumati, hoti autōn estin hē basileia tōn ouranōn. (Vergelyk ook Matt 5:4-10 en Luk 6:20-21.)

Matt 13:16 humōn de makarioi hoi of thalmoi hoti blepousin, kai ta öta humōn hoti akouousin.

Matt 16:17 makarios ei, Simōn Bariōna, hoti sarx kai haima ouk apekalupsen soi all' ho patër mou ho en tois ouranois.

Luk 1:45 makaria hē pisteusasa hoti estai teleiōsis tois lelalèmenois autē para kuriou.

Jak 1:12 makarios anēr hos hupomenei peirasmon, hoti dokimos genomenos lēmpsetai ton stefanon tēs zōès...

Die groeperinge onder (b) (predikatiewe adjektief) kan in die lig van bogenoemde vergelykende tabel as ' $n$ tipiese groep gereken word, ten spyte daarvan dat daar 'n sintaktiese verskil tussen groepe (i) (predikatiewe adjektief wat funksioneer as die logiese mikpunt in die segging) en (ii) (predikatiewe adjektief wat funksioneer as die uitgangspunt in die segging) bestaan. Die uitdrukkinge waarin die predikatiewe adjektief makarios, -ia, -ios voorkom, vertoon naamlik 'n vaste sintaktiese aforistiese vorm.

Wanneer al die relevante kontekste inhoudelik nagegaan word en daar word gelet op sowel die leksikaliese betekenis as die gebruik (vir 
verduideliking van terminologie, kyk onder andere Van Aarde HTS $36 / 3$ en 4, 1 v) van die tersake woorde, dan kan die semantiek van die betrokke woordgroep soos volg omskryf word (vgl ook Van Aarde HTS $36 / 3$ en 4,11 ). In al die gevalle (vyf en vyftig keer in agt en dertig perikope in die Nuwe Testament) dien die woord makarios, -ia, -ion en die stamverwante derivate (makarizö/makariō; makarismos) as geluk-aankondiginge. Twee en vyftig keer het dit die semantiese funksie van psigologiese gebeure en kan daarom getipeer word as abstrak-gebeurewoorde. (Vir verduideliking van terminologie, kyk onder andere Nida en Taber 1974: $37 \mathrm{v}$ ). Dit druk naamlik 'n kwalitatiewe toestand uit, maar dui tog ook 'n proses aan. As ons die "gebruike" in al twee en vyftig gevalle nagaan, dan merk ons dat, met die uitsondering van Handelinge $26: 2$ en Galate 4:15, dit na 'n religieuse heilsaankondiging van 'n soort blydskap of geluk verwys wat op een of ander wyse deelname aan die Christelike eskatologie impliseer. In Handelinge 26:2 en Galate 4:15 vind ons 'n verwysing na ' $n$ nie-religieuse tipe blydskap. Die laaste drie gevalle (1 Tim 1:11; 6:15 en Tit 2:13) kan as ' $n$ "suiwer" abstrak getipeer word. Hulle "gebruike" verskil in dié opsig dat in eersgenoemde twee gevalle dit na 'n predikaatseienskap van God verwys en die ander na 'n predikaatseienskap van 'n onpersoonlike gawe van God.

Die predikatiewe adjektief makarios, -ia, -ion in die segginge wat ons hierbo formeel as ' $n$ tipiese groep geïsoleer het, vertoon almal dus dieselfde inhoudelike strekking: Dit is ' $n$ abstrak-gebeurewoord wat 'n psigologiese proses van 'n geluk-aankondiging aandui en wat verwys na die blydskap wat die deelname aan die Christelike eskatologie meebring.

Hiermee is bewys dat die onderhawige literêre uitdrukking 'n geïdentifiseerde Gattung verteenwoordig,. Dit kan ons die Gattung "makarisme" noem.

\section{Die identifisering van die "makarismereeks" as Gattung}

In Matteus 5:3-10 vind ons dat die makarisme binne ' $n$ baie fyn en kunstig gestruktureerde perikoop in 'n reeks van agt versamel is (Van Aarde HTS 36/3 en 4, 5-7). Klaus Koch (1974: 21-23) is van mening dat daar agter hierdie makarismereeks 'n "gattungsgeschichtliche" verlede opgesluit lê. Hy is naamlik van oortuiging dat die makarisme aanvanklik nie in reekse ontstaan het nie, maar wel as enkelvoudige aforismes. Dit is eers later in reekse begin versamel. Wanneer die ontwikkeling van 'n bepaalde Gattung 'n verandering van literêre vorm meebring, dan kan daar in sodanige gevalle nie meer van dieselfde literêre vorm sprake wees nie (Van Aarde HTS 36/1 en 2, $69 \mathrm{v}$ ). Implisiet in Koch se oortuiging dat die makarismereeks die resultaat is van ' $n$ "geschichtliche" ontwikke- 
ling, bestaan daar dus die moontlikheid dat die reeks as sodanig 'n Gattung van sy eie verteenwoordig. Die aspek "Geschichtlichkeit" kan nie as kriterium aangelê word om Gattungen te identifiseer nie (Richter 1970: 216). Die "gattungsgeschichtliche" vraag wat in wese diakronies van aard is, is 'n faset van Gattungsforschung met sy eie bepaalde metodiese plek wat eers aan die einde tereg kom. Koch se opmerkinge noodsaak ons egter om intussen op sinkroniese gronde vas te stel of die makarismereeks in Matteus 5:3-10'n Gattung verteenwoordig of nie.

Met bovermelde doel voor oë is dit dus nodig om weer eens alle gevalle in die Nuwe Testament na te gaan wat moontlik in 'n tipiese groep saamgevat kan word. Omdat ek reeds in 'n ander artikel (HTS $36 / 3$ en $4,4-7)$ ' $n$ uiteensetting gegee het van die struktuur van die reeks in Matt 5:3-10, word dit nie hier herhaal nie. Die volgende gevalle verdien vervolgens dan ons aandag.

(a) Luk 6:20-22; 24-26

makarioi hoi ptóchoi, hoti humetera estin hè basileia tou theou.

makarioi hoi peinōntes nun, hoti chortasthēsesthe.

makarioi hoi klaiontes nun, hoti gelasete.

makarioi este hotan misēsōsin humas hoi anthrōpoi kai hotan aforisõsin humas kai oneidisösin kai ekbalōsin to onoma humön hōs ponēron heneka tou huiou tou anthröpou.

plèn ouai humin tois plousiois, hoti apechete tèn paraklèsin humōn. ouai humin, hoi empeplēsmenoi nun, hoti peinasete. ouai, hoi gelōntes nun, hoti penthèsete kai klausete. ouai hotan humas kalós eipōsin pantes hoi anthrōpoi, kata ta auta gar epoioun tois pseudoprofétais hoi pateres autōn.

In hierdie gedeelte vind ons 'n reeks van vier makarismes teenoor vier ooreenstemmende wee-uitroepe. Die posisie wat hierdie gedeelte by Lukas se Veldrede inneem, is presies dieselfde as dié by Matteus se Bergrede. Inhoudelik stem die vier makarismes in hierdie gedeelte ook grootliks ooreen met vier van die reeks in die Matteusevangelie. Agter hierdie uitsprake moet daar heelwaarskynlik, soos ook algemeen aanvaar word, 'n gemeenskaplike bron veronderstel word. In die Lukaspassasie (die "makarisme" saam met die ooreenstemmende "wee-uitroep") het ons met 'n bekende en goed ontwikkelde literêre produk van sy eie aard te doen (vgl Dodd 1969: 3 v). Die Gattung "makarisme" en die Gattung "wee-uitroep" dien hierin as vormelemente (Gliedgattungen) van 'n uitgebreide Gattung wat ons nie net 'n Rahmengattung kan bestempel nie, maar ook 'n Gattungsmischung. (Vir verduideliking van terminologie, kyk Van Aarde HTS 36/1 en 2,69.) Lukas wend hierdie Gattungsmischung in 'n reeks van vier aan. 
Hoe die oorspronklike vorm van die makarismes in die gemeenskaplike bron ookal daarna uitgesien het, dit is duidelik dat die aforistiese makarisme in beide die Matteus- en Lukasperikoop in 'n reeks versamel is. Hoewel die twee gedeeltes formeel en inhoudelik nie presies identies is nie, is hulle ooreenkomste egter sodanig dat hulle wel as ' $n$ tipiese groep getipeer kan word. Immers, eenhede hoef nie sjablone ten opsigte van mekaar te wees alvorens hulle as 'n bepaalde Gattung gegroepeer kan word nie. Richter (1971: 138; my kursivering) praat in dié verband van eenhede wat "gleich oder verwandt" ten opsigte van mekaar is. In die lig daarvan dat daar eers van 'n Gattung gepraat kan word as ten minste twee onafhanklike literêre eenhede struktureel en inhoudelik ooreenkoms moet toon, is die feit dat die twee betrokke passasies van 'n gemeenskaplike bron afhanklik is, egter geen diskwaklifikasie om die "reeks" nie 'n Rahmengattung te noem nie. Ons het in Lukas 6:20 vv en Matteus 5:3 vv totale onafhanklike arbeid van twee verskillende outeurs wat (hoewel van 'n gemeenskaplike bron afhanklik) nie ten opsigte van mekaar in hulle literêre arbeid afhanklik was nie.

(b) Luk 11:27-28

egeneto de en tō legein auton tauta eparasa tis fōnēn gunē ek tou ochlou eipen autō, Makaria hẻ koilia hē bastasasa se kai mastoi hous ethèlasas.

autos de eipen, Menoun makarioi hoi akouontes ton logon tou theou kai fulassontes.

In Lukas 11:27-28 kom daar twee makarismes in twee opeenvolgende kola voor. Die tweede makarisme staan in ' $n$ antitetiese parallelisme teenoor die eerste. Jesus wys naamlik daarop dat die ware "geluk" (= eskatologiese vreugde) nie geleë is om bloot die moeder van Hom te wees nie, maar wel daarin dat sy lering gehoor en onderhou word.

(c) Luk 12:37, 38, 43

makarioi hoi douloi ekeinoi, hous elthōn ho kurios heurései grègorountas.

.......

kan en tẽ deutera kan en tẽ tritẽ fulakē kai heurē houtōs, makarioi eisin ekeinoi.

makarios ho doulos ekeinos, hon elthōn ho kurios autou heurèsei poiounta houtos.

In hierdie gedeelte word drie makarismes binne dieselfde perikoop (12:35-48) aangetref. Hoewel dit nie opeenvolgens na mekaar voorkom nie, staan dit tog in 'n logiese verband. Die middelste maka- 
risme funksioneer (anders as die ander twee) sintakties as die logiese mikpunt in die segging. Dit maak dat ons inderdaad van 'n gebalanseerde "reeks" kan praat. Dit is opvallend dat die makarismes in hierdie gedeelte telkens inhoudelik die samevatting is van die skopus van die perikoop.

(d) Luk 23:29

hoti idou erchontai hèmerai en hais erousin,

Makariai hai steirai kai hai koiliai hai ouk egennēsan kai mastoi hoi ouk ethrepsan.

Dit is moontlik dat die woord makarioi in die dieptestruktuur in konstituente verbinding met die objek mastoi veronderstel moet word sodat ons in die bobou twee aparte subkola het wat afhanklik is van erousin. Dit sal dan inhou dat ons twee makarismes in hierdie gedeelte het wat direk op mekaar volg, maar waarvan delesie van die laaste veronderstel moet word. Myns insiens is die verskynsel van delesie hier nie teenwoordig nie, aangesien kai steirai, hai koiliai en mastoi hier as 'n semantiese eenheid opgeneem moet word wat een en dieselfde referensiële betekenis het. Dit geld ook vir Matteus 13:16.

(e) Rom 4:7-8

makarioi hōn afethèsan hai anomiai kai hōn epekalufthēsan hai hamartiai

makarios anēr hou ou mè logisètai kurios hamartian.

Hierdie gedeelte is 'n sitaat van Psalm 32:1-2 wat woordeliks uit die Septuaginta oorgeneem is, behalwe dat die laaste stige van die Hebreeus nie gesiteer is nie. As die hemistiges buite rekening gelaat word, dan vind ons hier twee opeenvolgende makarismes.

(f) Opb 1:3

makarios ho anaginōskōn kai hoi akouontes tous logous tès profēteias kai tèrountes ta en autē gegrammena, ho gar kairos engus.

In die dieptestruktuur vind ons hier drie makarismes. Ten opsigte van die laaste twee het daar op die bobou delesie plaasgevind. Dit is egter 'n vraag of só 'n geval inderdaad as 'n reeks opgeneem kan word. Dit geld ook vir Opb 16:15 waar daar ook 'n moontlikheid van delesie bestaan.

Die logiese gevolgtrekking wat uit bovermelde gegewens voortvloei is dat die Gattung "makarisme" meerdere male in die Nuwe Testament in kombinasies gebruik word waarvan die ooreenkomste sodanig is dat ons kan sê 'n "makarismereeks" daardeur gebou word. Dit kom in 
twee gedeeltes (Matt 5:3-10 en Luk 6:20 vv) in 'n "suiwer" vorm voor. Romeine 4:7-8 kom sintakties die naaste aan die reeks wat ons in bogenoemde twee passasies aantref. Hoewel ons in Lukas 11:27-28 en 12:35-48 nie 'n reeks in die sin van bogenoemde het nie, bestaan daar egter wel 'n verwante ooreenkoms deurdat die makarismes mekaar in die betrokke perikope in 'n logiese verband opvolg. Die res van die gevalle wat ondersoek is, se verskille is sodanig dat hulle nie deel van hierdie geïsoleerde tipiese groep gereken kan word nie. Klaus Koch het dus metodologies die kar voor die perde ingespan toe hy beweer het dat daar 'n "gattungsgeschichtliche" ontwikkeling van 'n enkelvoudige aforisme tot 'n reeks veronderstel moet word. Uit ons sinkroniese ondersoek het dit egter tog geblyk dat die Gattung "makarisme" as 'n vormelement binne die Rahmengattung "makarismereeks" aangewend word.

Vier ander gevalle buite die Nuwe Testament, maar wel deel van die Judaïca, het onder my aandag gekom wat die tese versterk dat ons in die "makarismereeks" van Matteus 5:3-10 en Lukas 6:20 vv met 'n Gattung van sy eie aard te doen het:

In Sirag 25:7-11 vind ons onmiskenbaar 'n Gattungsmischung. Die outeur kombineer hier die aforistiese "makarisme" met die chokmatiese "getallespreuk" van tien. Dit hou in dat hy noodgedwonge die makarisme in ' $n$ reeks moet opbou om by die getal tien uit te kom. In die inleiding (vs 7) kondig hy die geluk aan (emakarisa) wat spruit uit tien tipes van menslike seëninge wat tegelykertyd 'n korrekte etiese lewe impliseer. Hoewel die uitdrukking makarios ho deina slegs twee keer voorkom, het ons die effek van tien makarismes wat simmetries rondom die twee uitdrukkinge opgebou is.

In 2 Slaw Hen 42:6-14 (vgl Charles 1913: 457) vind ons 'n reeks van nege makarismes en in hoofstuk 52:1-16 (vgl Charles 1913: $461 \mathrm{v}$ ) 'n reeks van sewe waar elkeen om die beurt deur 'n ooreenstemmende "wee-uitroep" afgewissel word. In beide die gedeeltes funksioneer die term "geregtigheid" prominent. Vergelyk 42:11 ("Blessed is who sows the seeds of righteousness, for he shall reap sevenfold") en 52:16 ("And now, children, keep your hearts from all unrighteousness, that you may inherit the weighing-scale of the light into eternity").

Albei hierdie passasies toon dus met sowel die Matteus- as die Lukasperikoop inhoudelike ooreenkoms. As in aanmerking geneem word dat die Slawiese Henogboek in ongeveer dieselfde tyd as die Matteus- en Lukasevangelie gedateer word en dat beide manuskripte tot ons beskikking op 'n vroeëre Griekse vertaling van 'n moontlike Hebreeuse oorspronklike teruggaan (vgl Rost 1971: 83 v), dan versterk dit my tese dat ons in die "makarismereeks" van Matt 5:3-10 met 'n bekende literêre produk te doen het.

Ten slotte verwys ek na 'n himne uit die Geoniese periode wat 
waarskynlik uit die Talmoediese tyd afkomstig is (vgl Daube 1956: 198). In hierdie himne vind ons 'n reeks van tien segginge waarin God as bärük aangespreek word. Die Hebreeuse terme bārük en 'ašrēe (die ekwivalent van die Griekse makarios, -ia, -ion) is semanties uitruilbaar. Eersgenoemde bevat slegs die addisionele supplementêre komponent dat dit God ook as objek van die seën kan insluit, terwyl dit by laasgenoemde nie die geval is nie (vgl die inskrywings in Hatch en Redpath 1954: 892). Met dit in gedagte is dit dus inderdaad moontlik dat hierdie himne ten minste formele verwantskap met die geïdentifiseerde makarismereeks in Matteus 5:3-10 vertoon. Daube (1956: $198 \mathrm{vv}$ ) wil juis dieselfde probeer bewys.

\section{Die Sitz im Leben van die Nuwe-Testamentiese makarisme}

Die begrip Sitz im Leben moet nie opgeneem word as 'n historiese grootheid in die sin dat daar vir elke Sitz im Leben 'n noue vaslegbare historiese datum gestel kan word nie. Dit is eerder só dat die Sitz im Leben aan ' $n$ bepaalde historiese periode gebonde is (vgl Tucker 1975:116). Hierdie feit is onder andere die rede waarom die vraag na die Sitz im Leben van ' $n$ formule soos die makarisme binne die Nuwe Testament nie só simplisties is nie. Want indien daar vasgestel kan word dat sommige van die makarismes in die Evangelies ipsissima verba Jesu is, kan die vraag gestel word na die Sitz im Leben Jesu. En as dit blyk dat daar makarismes in die Nuwe Testament is wat as "Gemeindebildung" opgeneem moet word (vgl Bultmann 1967: 115; Koch 1974: 53), dan moet daar weer gevra word na die Sitz im Leben der alten Kirche. Ons sal moet aanneem dat die evangelis Matteus in die midde van die vroeg-Christelike gemeente gestaan het, en dat hy sy evangelie waarskynlik dus met die oog op die gemeente geskryf het (Klijn 1968: 45). Wat hierdie aangeleentheid betref, moet in die algemeen die vroeë Christelike kerugma, die vroeë Christelike erediens en die vroeë Christelike kategese waarskynlik as die Sitze im Leben der alten Kirche beskou word (Zimmerman 1974: 173).

Koch (1974: 36) wys daarop dat dit nie meer herkenbaar is by watter geleentheid in die vroeg-Christelike gemeente die makarisme voorgedra is nie. Die Ou-Testamentiese gebruik om makarismes as die aanvang van ' $n$ wysheidsrede te stel en die plasing van die makarismereeks in Matt 5 as die aanvang van die Bergrede en by Lukas as die aanvang van die Veldrede, laat hom vermoed dat dit binne die raamwerk van die "Predigtgottesdienst" voorgekom het, en dan as die "Ausgangstext" van die verkondiging aan die gemeente.

In dié verband huldig Joachim Jeremias (1972) 'n besonder interessante teorie. In die lig van die breë onderskeiding tussen kerugma en 
didachē in die vroeë kerk waar die kerugma die verkondiging van die verlossing in Christus aan die heidene is, en die didach $\bar{e}^{\prime} n$ instruksie met dieselfde inhoud as die kerugma aan die Christelike gemeente is (Dodd 1939), beskou Jeremias (bl 21) die Bergrede in sy geheel as 'n klassieke voorbeeld van 'n vroeg-Christelike didachē. Vir Jeremias is die Bergrede se Sitz im Leben der alten Kirche dan geleë in die kategetiese onderrig aan nuut gedoopte Christene ("postbaptismal"). Die verskillende geisoleerde logia waaruit die Bergrede dan aanvanklik sou bestaan het, is dus deur die evangelis met die oog op 'n paranetiese doel versamel. Die logiese gevolg is dan dat as die Bergrede 'n kategetiese onderrig aan dooplidmate, of aan nuut gedoopte Christene is, dit deur iets anders voorafgegaan moes gewees het. "It was preceded by the proclamation of the Gospel; and it was preceded by conversion, by being overpowered by the Good News (bl 24) . . . It is as if to every saying of the Sermon on the Mount we must supply the Protasis: 'your sins are forgiven' (Matt 9:2)" (bl 29). Hierdie "Good News" die "protasis", is die kerugma, en dit moet volgens Jeremias dwarsdeur die Bergrede (didachē) voor elke logion veronderstel word. "The kerugma is now followed by the didachē. Moreover, the protasis is only ostensibly missing: It is found at the beginning of the Sermon on the Mount in the form of the beatitudes 5:3-12), and in the sayings on the glory of the discipleship (5:13-16). These two sections concern the whole sermon just as in a mathematical formula a number before a bracket. They concern every saying in the Sermon on the Mount, they are simply not repeated every time" (bl 30; kursivering deur Jeremias). Vir Jeremias kom dit by implikasie daarop neer dat die makarismereeks in die vroeë kerk 'n belangrike rol by die doop gespeel het. G Braumann (1960: 259) het ook in 'n ondersoek die doop as die Sitz im Leben van die makarismereeks aangedui: "Der Schluss aus diesen Beobachtungen wird demnach der sein, dass die untersuchte Sonderüberlieferung des Matthäus zunächts die Tauftheologie der urchristlichen Gemeinde als ihren Sitz im Leben hatte"...

Jeremias se bevinding met betrekking tot die posisionele funksie van die makarismereeks in Matt 5 toon in sekere opsigte opvallende ooreenkoms met my eie resultaat in dié verband (HTS 36/3 en 4, 10). Tog bly die teorieë van Jeremias en Braumann ten opsigte van die Sitz im Leben van die makarismereeks hipoteses wat nie bo alle twyfel bewysbaar is nie. Dit lyk dus nie of dit moontlik is om 'n definitiewe aanduiding van die gemeentelike Sitz im Leben van die Nuwe-Testamentiese makarisme te gee nie. Slegs die feit dat 'n groot getal daarvan sintakties as die uitgangspunt van 'n segging figureer (vergelyk Klaus Koch), is net nie genoegsaam om die gemeentelike Sitz im Leben van die makarisme as die liturgiese "Ausgangstext" van die "Predigtgottesdienst" op te neem nie. Volgens Richter (1971: 145) 
moet die Sitz im Leben vanuit die struktuur en die inhoud van die Gattung afgelei word - indien moontlik (vgl. Van Aarde HTS 36/1 en $2,67)$. Wat die Nuwe-Testamentiese makarisme betref, is die struktuur en die inhoud daarvan ongelukkig nie genoegsaam om sy spesifieke gemeentelike Sitz im Leben raak te sien nie. Inhoudelik varieer die Nuwe-Testamentiese kontekste waarin die makarisme voorkom. In die een geval word die makarisme byvoorbeeld gebruik op grond van die lyding wat die aangesprokene vanweë "vyandiges" moet verduur, en in die ander geval word dit gebruik in terme van 'n korrekte etiese lewe. Die inhoudelike element wat wel in die makarismes binne die Nuwe Testament konstant teenwoordig is, is dat die makarisme ' $n$ religieuse geluk-aankondiging is wat verband hou met die eskatologiese heil. Dit lyk dus of ons met ' $n$ vae aanduiding ten opsigte van die Sitz im Leben van die Nuwe-Testamentiese makarisme sal moet volstaan: Die vroeg-Christelike eskatologiese heilskerugma.

\section{Die funksie van die makarismereeks in Matteus 5:3-10}

Die vraag na die "funksie" van die Gattung is die vraag na die verhouding tussen die Sitz in der Literatur van 'n konkrete tekseenheid wat ' $n$ manifestasie is van 'n bepaalde Gattung, en die tipiese Sitz im Leben van dié betrokke Gattung (Markert 1973: 95; Van Aarde HTS 36/1 en 2, $67 \mathrm{vv}$ ). Met ander woorde, die vraag na die Sitz in der Literatur kom eers aan die orde by die aanwending van die betrokke Gattung in aktuele taalgebruik. Die vraag na die "funksie" van 'n Gattung is dus die vraag of die Gattung "funktionstypisch" of "funktionsatypisch" in 'n konkrete gebruiksgeval aangewend is (Hoffman 1970: 344 v). Met hierdie vraag word daar in Gattungsforschung weggedoen met die tradisionele opvatting dat 'n Gattung 'n buite-literêre grootheid is. Ons is nou geïnteresseerd in die vraag na die funksie van die makarismereeks in Matteus 5:3-10.

Die perikoop Matteus 5:3-10 beklee 'n besondere posisie binne sy wyere konteks, naamlik Matteus 4:23-9:35 (vgl Van Aarde HTS 36/3 en 4, 7-10). Laasgenoemde gedeelte vorm ' $n$ ringskomposisie. Die identiese inleiding (4:23) en slot (9:35) gee by wyse van drie partisipiale frases (didaskōn ..., kerussōn ..., therapeuōn ...) 'n aanduiding van die dominerende inhoudsmomente van die passasie. Dit is naamlik 'n didaktiese motief, 'n kerugmatiese motief en 'n genesingsmotief. Die genesingsmotief kom hoofsaaklik in die wondervertellinge van hoofstukke 8 en 9 na vore. In die Bergrede (hoofstukke 5-7) figureer die didaktiese motief dominant. Die wondervertellinge word verder ook deur vertellings oor onderwysings van Jesus onderbreek. Die tersake perikoop (5:3-10) vorm die exordium van die Bergrede. Binne hierdie besondere prominente struktureel- 
semantiese posisionele eenheid maak Matteus van ' $n$ bepaalde Gattung gebruik, naamlik die makarisme. Met herhaling daarvan word dit 'n vormelement van 'n nuwe Gattung - die makarismereeks.

Die tipiese Sitz im Leben van die makarisme pas die evangelis ideaal. Hierdie tipiese Sitz im Leben is hierbo omskryf as 'n gelukaankondiging wat as 'n eskatologiese heilskerugma verstaan moet word. Die kerugmatiese kwaliteit van die makarismereeks (die exordium van die Bergrede) verleen ook kerugmatiese gehalte aan die res van die didaktiek in die Bergrede. En omdat die didaktiese passasies in die wyere konteks (waarvan die Bergrede die eerste sodanige gedeelte is) met die wondervertellinge (veral genesings) alterneer, moet hierdie didaktiese passasies ook kerugmaties bepaald wees op grond van die inleidingsdidaktiek in die Bergrede. Dit geld daarom ook vir die alternerende wondervertellinge. Kortliks saamgevat kom dit daarop neer dat die kerugmatiese motief in die wyere konteks sy plek binne die makarismereeks kry.

Dit is duidelik dat vir die konteks onder bespreking weinig ander Gattungen meer funksioneel en effektief sou wees as juis die makarisme, en wel in 'n reeksvorm. Daarom dui die Sitz in der Literatur van die makarismereeks in Matteus 5:3-10 aan dat dié Gattung hier besonderlik "funktionstypisch" aangewend is.

\section{Die Gattungsgeschichte van die Nuwe-Testamentiese makarisme}

Die makarisme as 'n spesifieke vaste Griekse literêre formule word nie net in die Nuwe Testament aangetref nie. Afgesien van die talle ander voorbeelde wat ons in die klassieke Grieks (kyk Hauck 1942: $365 \mathrm{v}$ ) en in die Hellenistiese Grieks buite die Nuwe Testament (kyk Kähler 1976: 48-50, 52 v) aantref, vind ons in die Septuaginta ses-enveertig voorbeelde wat voldoen aan die vereistes van dié wat ons in die Nuwe Testament op grond van 'n formele ondersoek tot 'n tipiese groep geklassifiseer het. Van hierdie ses-en-veertig gevalle is sewe-en-dertig ' $n$ weergawe van die ekwivalente Hebreeuse 'ašrçformule. Een en twintig gevalle word in die Psalms aangetref, ses in Spreuke, drie in Jesaja en een elk in Deuteronomium, 1 Konings, 2 Kronieke, Trito-Jesaja, Job, Prediker en Daniël. In Romeine 4:7-8 vind ons ook 'n sitaat uit die Septuaginta van Ps 32:1-2. Hierdie gegewens laat ons vermoed dat die Nuwe-Testamentiese makarisme 'n geskiedenis het. Maar dan nie 'n geskiedenis wat gesoek moet word in die literatuur van die klassieke Griekeland of dié van die Helenistiese wêreld nie (Koch 1974: 23), maar wel in die Ou Testament via die Septuaginta, en in die Judaïca. Die ondersoeke wat onder andere Walter Käser (1970: 225-250), asook Waldemar Janzen (1965:215-226), na die vorm en inhoud van die 'ašrẹ-uitsprake binne die Ou Testament gedoen het, is hiervoor ' $n$ bewys. 
Dit beteken egter nie dat die Ou-Testamentiese 'ašrệ-formule presies in alle opsigte met die Nuwe-Testamentiese makarisme hoef ooreen te stem nie. In dié opsig het Käser genoegsaam aangetoon dat daar juis nie só 'n grammatiese ooreenkoms bestaan nie. Die woord 'ašrẹ is byvoorbeeld grammaties 'n status constructus meervoud, en is wat getal, geslag en modus betref, onafhanklik ten opsigte van die daaropvolgende nomen - anders as sy Nuwe-Testamentiese ekwivalent (Käser 1970:230). Sintakties en inhoudelik bestaan daar egter baie duidelik ooreenkomste, hoewel die 'ašrề-formule slegs in 'n sekere opsig as die voorloper van die Nuwe-Testamentiese makarisme beskou kan word.

Käser het sintakties aangetoon dat die woord 'ašrẹ in die reël die "Spitze" vorm van die segging wat daarop volg, en sodoende op grond daarvan beklemtoning verkry. Hierbenewens het Klaus Koch (1974:8) daarop gewys dat daar ook voorbeelde is waar die woord 'ašrē as die logiese mikpunt van die segging figureer (vergelyk Spr $14: 21 ; 16: 20 ; 29: 18$ ) (Käser vra die vraag of hierdie drie gevalle uit Spreuke nie eerder as "Stileigenheit des Redaktors" beskou moet word nie.)

Hierdie feite stem sintakties feitelik met die Nuwe-Testamentiese makarisme ooreen. Dit is egter nie die enigste nie; daar bestaan nog verdere belangrike sintaktiese ooreenkomste. Dikwels kom die 'ašrềformule net soos in die geval van die Nuwe-Testamentiese makarisme slegs in ' $n$ enkelvoudige segging voor sonder ingebedde uitbreidinge (vergelyk byvoorbeeld Ps $34: 9 b$ 'ašrē haggeber yeh ${ }^{\boldsymbol{e}}$ se bō met Luk 14:15 makarios hostis fagetai arton en té basileia tou theou). In ander gevalle weer word die matrikssin uitgebrei met 'n relatiewe bysin (verglyk Ps 94: 12a 'ašrē haggeber ${ }^{a}$ šer $\boldsymbol{t}^{\boldsymbol{e}}$ yass $\boldsymbol{e}_{\text {rennū yah met }}$ Matt 11:6 makarios estin, hos ean mē skandalisthē en emoi), of 'n

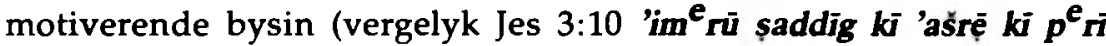
ma $^{c}$ allēhem yo kelū met Matt 5:2b-3 edidasken autous legōn. Makarioi hoi ptōchoi tō pneumati, hoti autōn estin hè basileia tōn ouranōn. (Die lesing in die teksapparaat van "Biblia Hebraica" word aanvaar en

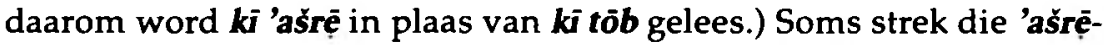
formule oor twee of drie stiges heen. Die woord 'ašrè moet by elkeen van hierdie stiges dan veronderstel word (vergelyk byvoorbeeld Spr

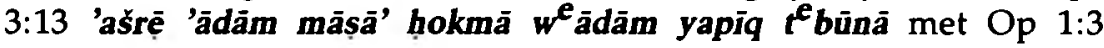
Makarios ho anaginōskōn kai hoi akouontes tous logous tès profēteias kai tērountes ta en autē gegrammena). Dikwels strek die inhoudelike wydreikte van die 'ašrề-formule ook verder as net die segging waarin dit voorkom (vergelyk byvoorbeeld Ps 41:2-4 met Matt 16:17-19. Laasgenoemde twee voorbeelde van die 'ašrē-formule is deel van dié groepering wat Käser (bl 225-229) die sogenaamde "gebonde makarismes" noem. Hy het al die Ou-Testamentiese voorbeelde in die Septuaginta as "gebundenen Makarismen" en "unge- 
bundenen Makarismen" geklassifiseer. Hy het die Wysheid van Jesus ben Sirag (waarin daar vier voorbeelde van die sogenaamde "gebonde makarisme" voorkom) by hierdie klassifikasie ingereken. Laasgenoemde is ook die groep wat in frekwensie die meeste voorkom. Op grond van die feit dat die wydreikte van die "gebonde makarisme" oor stiges en/of kola strek, kan ons dit as 'n gegewenheid beskou dat die meeste Ou-Testamentiese makarismes (Septuaginta en Judaïca ingesluit) in hulleself die beginsel van uitbreiding bevat.

Wat die inhoudelike aspek van die Ou-Testamentiese 'ašrệ-formule betref, het W Käser (bl 249 v) tot die volgende gevolgtrekking gekom: "Sie ist Verkündigung der durch Gnade geschaffenen, durch Gnade aufrechterhaltenen, durch Gnade dem eschatologischen Ziel entgegengeführten Relation zwischen Gott und Mensch im Lebensbund der Gnade; dies gilt auch und gerade von den überaus zahlreichen thorabezogenen Makarismen. Im Blick auf den gestern, heute und morgen sich treubleibenden Herrn des Bundes ist die makarismische Verkündigung wesenhaft eschatologisch. Dass das eschatologische Ziel oft auf eine innergeschichtliche Zukunft verkürzt erscheint - eine Beobachtung, die der ntl. Seligpreisung fremd ist spricht noch einmal dafür, dass der Gott dieses Bundes (und also dieser Relation) der Herr aller Geschichte ist. Im Blick auf ihn ist die Existenz des Menschen in dieser Relation (der ntl. Seligpreisung wiederum so gut wie unbekannt) als die des vom Gesetz Jahwes umhegten Lebens beschrieben. Die drei fur den alt. Makarismus wesentlichen Momente der Relation, der eschatologischen Orientierung und der Verknüpfung des Heilszuspruches in die Thora als der Form des Lebens aus Jahwe lassen sich mehr oder minder ausgeprägt. Darin aber klingen die makarismischen Zeugnisse des AT und NT in eins susammen: Seligpreisung ist Lobpreis der heilschaffenden Gnade Gottes am erwählten Menschen" (kursivering deur Käser).

Die Nuwe-Testamentiese makarisme het sy wortels in die Ou Testament. Die voorbeelde van makarismereekse in die Nuwe Testament (asook dié in Sirag 25:7-11, 2 Slaw Hen 42:6-14 en 52:1-16) het waarskynlik hulle aanknoping by die Ou-Testamentiese "gebonde makarismes" gevind. Sodoende is 'n stuk Ou-Testamentiese kerugma in die Nuwe Testament gekontinueer - hoewel met 'n nuwe inhoud gevul.

\section{Verwysings}

Braumann G, 1960: Zum traditionsgeschichtlichen Problem der Seligpreisungen Mt v 3-12, NT 4 (1960), 253-260.

Charles RH, 1913: The apocrypha an pseudepigrapha of the Old Testament in English II, Oxford: Clarendon. 
Bultmann R, '1967: Die Geschichte der synoptische Tradition, Göttingen: Vandenhoeck \& Ruprecht.

Daube D, 1956: The New Testament and Rabbinic Judaism, Londen: Athlone.

Dodd $\mathrm{CH}, 1939$ : The apostolic preaching and its developments, Londen: Hodder \& Stoughton.

Dodd CH, 1968: The beatitudes: a form critical study, in More New Testament Studies, Grand Rapids: Eerdmans.

Hatch E en Redpath HA, 1954: A concordance to the Septuagint and other Greek versions of the Old Testament I, Graz: Akademischen Drruck-u. Verlagsanstalt.

Hauck F, 1942: sv makarios ktl in ThWNT IV, Stuttgart: W. Kohlhammer Verlag.

Hoffmann HW, 1970: Form-Funktion-Intention, ZAW 82 (1970), 341-346.

Janzen W, 1965: 'AŠRE in the Old Testament, HThR 58 (1965), 215-226.

Jeremias J, ${ }^{2} 1972$ : The sermon on the mount, Londen: Athlone.

Kähler C, 1976: Zur Form- und Traditionsgeschichte von Matt XVI. 17-19, NTS 23 (1977), 36-58.

Käser W, 1970: Beobachtungen zum alttestamentlichen Makarismus, ZAW 82 (1979), 225-250.

Klijn AFJ, 1968: De wordingsgeschiedenis van het Nieuwe Testament, Utrecht/Antwerpen: Het Spectrum NV.

Koch K, ${ }^{3} 1974:$ Was ist Formgeschichte? Neue Wege der Bibelexegese, Neukirchen-Vluyn: Neukirchener Verlag.

Markert L '1976: Formen- und Gattungskritik, in G Fohrer ea, Exegese des Alten Testaments. Einführung in die Methodik, Heidelberg: Quelle \& Meyer.

Nida EA en Taber CR, 1974: The theory and practice of translation, Leiden: Brill.

Richter W, 1970: Formgeschichte und Sprachwissenschaft, ZAW 82 (1970), 216-225.

Richter W, 1971: Exegese als Literaturwissenschaft. Entwurf eine alttestamentlichen Literaturtheorie und Methodologie, Göttingen: Vandenhoeck \& Ruprecht.

Rost L, 1971: Einleitung in die alttestamentlichen apokryphen und pseudepigraphen, Heidelberg: Quelle \& Meyer.

Tucker GM, ${ }^{3}$ 1975: Form criticism of the Old Testament, Philadelphia: Fortress.

Van Aarde AG, 1978: Die "betekenis" van die makarismereeks in Matteus 5-semantiek en Gattungsforschung, MA-verhandeling Universiteit van Pretoria.

Van Aarde AG, HTS 36/1 \& 2: 'n Nuwe benadering tot Gattungsforschung, 58-73.

Van Aarde AG, HTS 36/3 \& 4: "Betekenis" en "gebruik" in die makarismereeks (Matt 5:3-10), 1-28.

Votaw CW, 1909: The sermon on the mount, in J Hastings (red), A dictionary of the Bible. Extra volume, Edinburgh: Clark.

Zimmerman H,7974: Neutestamentlichen Methodenlehre. Darstellung der historisch-kritischen Methode, Stuttgart: Katholische Bibelwerk. 